\title{
15 Social Enterprises in Rural Areas
}

\author{
A Comparative Study \\ of the Baltic States
}

Roger Evans, Mervi Raudsaar, Làsma Lììite-Kurbe, Eglè Butkevičienè, Philipp Erpf, Audronè Urmanavičienè and Agota Giedré Raišienè

\section{Introduction}

Since 1991, social enterprises (SEs) in the Baltic states have grown into important actors in tackling social and environmental problems; however, their development remains strongly influenced by the region's recent turbulent history. The Baltic countries were occupied and incorporated within the Soviet Union in the periods 1940-1941 and 1944-1991. Following the restoration of independence, the political system became favourable, after a long period of centrally planned economies, to the development of private business. These economic and political changes opened up new opportunities for private entrepreneurship and civil society. Although SE development in the Baltic states is still influenced by this history, the number of social enterprises is steadily increasing, filling the gaps left by the state and the market in the provision of social services (Pless 2012).

Declining social services and relatively higher rates of unemployment and poverty levels (by comparison with urban areas) are just some of the challenges facing rural communities. Social enterprises can thus play a key role in rural development. Researchers argue that social enterprises pursue social missions through entrepreneurial means and implement social innovation (Dees 2001; Schöning 2013). In rural regions, social enterprises often simultaneously address the needs of multiple stakeholders and as such may have multiple functions and duties: delivering public services, meeting social needs, providing training and education to local community residents and creating working places.

This research aims to explore the evolution of rural social enterprises in the Baltic states by highlighting the factors that influence their 
development and the interplay among their different stakeholders. Specifically, the article addresses the following aspects:

- processes and factors that facilitate or hinder the development of rural social enterprises, financial and policy challenges and barriers encountered and ways in which social enterprises overcome them;

- collaborations developed between social enterprises and their stakeholders and clients;

- development support needs of social enterprises;

- rural SE models.

This chapter provides information about the earlier issues by presenting a cross-case analysis of rural social enterprises from Latvia, Lithuania and Estonia.

\section{Social Enterprises in a Rural Context: The Role of Environment and Stakeholders}

Social enterprises seek to produce goods and services with a social or environmental purpose, and they pursue the general interest of local communities, people and/or social groups. They thus aim to achieve dual goals-combining economic sustainability with the implementation of societal goals (Erpf 2017; Raišienè and Urmanavičiene 2017, Erpf et al. 2020). The orientation towards the public good does not imply that social enterprises do not undertake strategies to achieve economic and financial efficiency; on the contrary, they must constantly create economic value to guarantee their survival over time (Costa and Pesci 2016).

The sustainability of a social enterprise- that is, its long-term, continuous operational capacity-depends on its operating environment and its relationships with its stakeholders (Perrini and Tencati 2006). Rural social enterprises face some specific challenges in this regard, due to the economic and socio-cultural environment within which they operate; this is particularly true when they attempt to address specific local needs and problems, although there are also common challenges with social enterprises in urban areas, such as underdeveloped infrastructure, lack of private investors and insufficient business skills.

Beside some tasks that can be similar across rural communities (such as providing self-help environments or serving as repositories of the mutual knowledge that characterise social life in many rural regions; see Atterton 2007), the aims of rural social enterprises can differ widely: providing health and care services (Munoz et al. 2015); creating new employment opportunities (Steiner and Teasdale 2019); providing public services (O'Shaughnessy et al. 2011); more broadly, contributing to 


\section{Evans, Raudsaar, Lìcite-Kurbe et al.}

rural development (Eversole et al. 2014; Steiner and Teasdale 2019). As emphasised by Steinerowski and Steinerowska-Streb (2012), social enterprises in rural areas can be an efficient form of doing business, since local community residents can identify their own needs and the challenges they face in daily life. Also worth underlining is the fact that, in rural communities, the "culture of self-help" and solidarity lending still remain, while they are almost lost in big cities.

The successful operation of rural social enterprises is highly dependent on their relationships with their stakeholders (Perrini and Tencati 2006). Stakeholder theory emphasises the benefits of engaging with stakeholders (Freeman 1994; Donaldson and Preston 1995); this is particularly important for social enterprises, qua "multi-stakeholder" organisations (Borzaga and Depedri 2015). Many interest groups can indeed be involved in social enterprises; they can be divided into external stakeholders (the community, the government, sponsors and private investors) and internal stakeholders (volunteers and employees) (Thompson and Martin 2010).

When seeking to pursue the different interests of their various stakeholders, social enterprises are faced with significant challenges (Courtney 2013; Smith et al. 2013). Hinrichs (2015) suggests a framework for defining and prioritising stakeholders; this framework includes elements such as the power exerted by stakeholders over the enterprise, their legitimacy and the urgency of their claim. Given their multidimensional nature, it is particularly important for social enterprises to design organisational solutions that allow the fulfilment of multi-focused stakeholder expectations (Di Domenico et al. 2009). Some of these organisations adopt an open and multi-stakeholder governance model, in which all categories of stakeholders have rights to participate in the management (Galera and Borzaga 2009). Such actions help to build and strengthen relationships based on trust between different groups of stakeholders.

\section{Historical Context of SE Development in Baltic States and Challenges in Rural Areas}

The occupation of the Baltic states by the Soviet Union lasted for about 50 years; during that period, all forms of entrepreneurship were prohibited, and farming was collectivised into kolkhozes (agricultural cooperatives) and sovkhozes (state-owned agricultural enterprises). The Soviet system influenced the economy, the quality of life and the prevailing standards of behaviour in all life areas (Pārsla 2011). After the collapse of the Soviet Union, a large part of the population had-and this is still the case today - a misleading picture of cooperatives, due to the failures of these organisations, which were in turn linked to ignorance of the true principles of cooperation.

This particularly affected the emergence and growth of social enterprises after 1991; unlike what happened elsewhere in the world, where 
many social enterprises chose a cooperative form, social enterprises in the Baltic countries emerged mainly under the legal forms of association and foundation, especially in Latvia and Estonia, or as limited-liability companies. Only recently, some 25 years after the end of Soviet occupation, have cooperatives started to become more popular.

As for the concept of "social enterprise", it was also affected by these countries' history: indeed, the notion of "social" was for many years linked to the concept of "socialism"; this remained true even after the demise of the Soviet Union and of its socialist ideology.

Post-socialist restructuring of the economy, the dissolution of Sovietera large-scale farms, the replacement of the planned economy with a market economy and the opening of Baltic states to Western producers (including food producers) had a strong impact on the rural economy, and poverty levels increased, especially in more peripheral areas. Poverty levels and income inequality between rural and urban populations remain high to this day. For example, in Lithuania, the proportion of the population at risk of poverty in 2016-2017 was $29.6 \%$; this rate has remained roughly stable over the past five years, with a significant difference between urban $(24.7 \%)$ and rural $(39.5 \%)$ populations (Jankauskaite 2019). Data from the Central Statistical Bureau of Latvia (2020) also show high income inequalities between regions: in 2018, in the capital city, Riga, and in the Pieriga region, the rate of persons whose revenues were below the minimum-income level was very low $(4.4 \%$ in Riga and $3.7 \%$ in Pieriga), while in the remote Latgale region, this rate reached $17.8 \%$. In Estonia, relative poverty is still growing, and agricultural employment fell from 175,000 in 1989 to 24,000 in 2014 (Annist 2017). In Lithuania, the share of the agricultural sector in the country's workforce decreased from $27 \%$ in 2013 to $22.6 \%$ in 2017 (Simonaityte 2019). In Latvia, this share decreased from 16\% in 1990 to $7 \%$ in 2017.

Rural emigration and migration to cities is a major issue in the three countries, following the economic and social changes of the 1990s. In all three Baltic states, people from rural areas leave their country more often than city inhabitants, or they migrate to cities. Emigration particularly increased in the 2000s, and especially after the Baltic states' accession to the EU, in 2004. Between 2001 and 2011, the population in peripheral rural areas declined by $25 \%$ in Estonia (Annist 2017) and by $12.11 \%$ in Lithuania (Butkute 2014); the decline rate reached 32\% between 2000 and 2011 in Latvia (Central Statistical Bureau of Latvia 2020). In recent years, though, depopulation slowed down in both Lithuania and Latvia (Statistics Lithuania 2019a; Central Statistical Bureau of Latvia 2019a), while Estonia's net migration became even positive (Statistics Estonia 2018). In fact, according to Seney and Hess (2018), emigration rates continue to be high but are counterbalanced by immigration. Growing immigration and inhabitants' migration from rural areas to the cities is 


\section{Evans, Raudsaar, Lìcite-Kurbe et al.}

characteristic of all Baltic States today (Statistics Lithuania 2019b; Central Statistical Bureau of Latvia 2019b).

While the three countries faced similar historical contexts and challenges, the solutions implemented to support the development of social enterprises differed.

Table 15.1 provides an overview of the SE phenomenon in the Baltic states in terms of existence or absence of a legal framework, definition of the concept and legal forms. Overall, the concept is still poorly understood in the region. In Latvia, a wide definition encompasses a variety of activities, including environmental issues. However, SE law allows social enterprises to operate only under the legal form of limited-liability companies. In Lithuania, enterprises that want to be granted the legal status of social enterprise have to adopt the legal form of a private or public limited-liability company, individual enterprise or small partnership company. Some social enterprises operate as public enterprises, but since 2015, public enterprises have not been allowed to apply for the legal status of social enterprise anymore. In Estonia, there is no specific law for social enterprises, and these initiatives mostly operate as nongovernmental organisations, foundations and private limited companies.

Although two of the three Baltic states have adopted a legal framework for social enterprise (which constitutes some kind of recognition, at the political level, of the importance of the sector) and one has not, the

Table 15.1 Characteristics of social enterprises in the Baltic states

\begin{tabular}{|c|c|c|c|}
\hline Characteristics & Lithuania & Estonia & Latvia \\
\hline $\begin{array}{l}\text { Law on social } \\
\text { enterprise }\end{array}$ & Since 2004 & None & Since 2018 \\
\hline $\begin{array}{l}\text { Definition } \\
\text { of social } \\
\text { enterprise }\end{array}$ & $\begin{array}{l}\text { Narrow definition, } \\
\text { embedded in the } \\
\text { Law on Social } \\
\text { Enterprise }\end{array}$ & No legal definition & $\begin{array}{l}\text { Wide definition, } \\
\text { embedded in the } \\
\text { Law on Social } \\
\text { Enterprise }\end{array}$ \\
\hline Legal form(s) & $\begin{array}{l}\text { Private and public } \\
\text { limited-liability } \\
\text { company, } \\
\text { individual } \\
\text { enterprise and } \\
\text { small partnership } \\
\text { company }\end{array}$ & $\begin{array}{l}\text { No specific legal } \\
\text { form for social } \\
\text { enterprise (most } \\
\text { operate as non- } \\
\text { governmental } \\
\text { organisations, } \\
\text { foundations and } \\
\text { private limited } \\
\text { companies) }\end{array}$ & $\begin{array}{l}\text { Limited-liability } \\
\text { company (LLC) }\end{array}$ \\
\hline
\end{tabular}


challenges that social enterprises are facing are similar in all three countries, to the extent that these frameworks have not completely solved conceptual problems. Indeed, many socially oriented companies are still not recognised as social enterprises, and a distinction can thus be made between de jure social enterprises and de facto social enterprises.

This leads us to consider the factors facilitating or hindering the development of rural social enterprises across the Baltic States in a comparative perspective, and to analyse whether these factors differ for each country or are common to all; who the clients of rural social enterprises are; and the kinds of collaborations being developed between social enterprises and their stakeholders. These factors are addressed based on empirical evidence.

\section{Methodology}

With a view to gathering qualitative data, ten semi-structured interviews were conducted with social entrepreneurs in Estonia, Latvia and Lithuania. Table 15.2 introduces interviewees and explains the types of enterprise they represent.

\section{Results and Discussion}

Interviewees expressed their opinions regarding the development processes of their social enterprise and the factors that foster or hinder the processes through which social enterprises cooperate with their different stakeholder groups.

\subsection{Factors Fostering/Hindering the Development of Social Enterprises}

Although the factors that influence the development of social enterprises vary among the three Baltic states, some similar tendencies can be identified. The main similarity concerns the cooperation with local governments: social enterprises in Estonia and Latvia build up trust with the local government, establishing partnerships in the provision of social services. In Lithuania, though, the cooperation between social enterprises and local governments is less developed than in the other two Baltic countries.

Social enterprises may also play a key role in consultations and through participation in policy-making procedures; in Latvia, for example, LV2 conducts annual surveys aimed at assessing the quality of municipal services and provides feedback on new services required in the future; this serves as the basis for subsequent procurement processes of the local government and ensures that the services provided are appropriate and useful. Furthermore, social enterprises consider that the focus they place 
Table 15.2 Empirical sample: list of interviewees/social enterprises

\begin{tabular}{|c|c|c|c|}
\hline Code & $\begin{array}{l}\text { Interviewee: } \\
\text { position in social } \\
\text { enterprise }\end{array}$ & $\begin{array}{l}\text { Legal form of the } \\
\text { social enterprise }\end{array}$ & $\begin{array}{l}\text { Type of social enterprise and } \\
\text { main activity }\end{array}$ \\
\hline LT1 & Owner & $\begin{array}{l}\text { Joint stock } \\
\text { company }\end{array}$ & $\begin{array}{l}\text { A small ecologically oriented } \\
\text { company producing healthy } \\
\text { food }\end{array}$ \\
\hline LT2 & Director & $\begin{array}{l}\text { Public } \\
\quad \text { organisation }\end{array}$ & $\begin{array}{l}\text { A rural public organisation } \\
\text { providing social services }\end{array}$ \\
\hline LT3 & Teacher & $\begin{array}{l}\text { Public } \\
\quad \text { organisation }\end{array}$ & $\begin{array}{l}\text { A public organisation providing } \\
\text { educational programmes } \\
\text { for children in local rural } \\
\text { communities }\end{array}$ \\
\hline LV1 & $\begin{array}{l}\text { Chairman of the } \\
\text { Board }\end{array}$ & NGO & $\begin{array}{l}\text { A Christian charity } \\
\text { organisation helping families } \\
\text { in crisis, children and lonely } \\
\text { people }\end{array}$ \\
\hline LV2 & Director & $\mathrm{NGO}$ & $\begin{array}{l}\text { One of the largest Latvian } \\
\text { social enterprises, with over } \\
700 \text { paid employees and } 300 \\
\text { volunteers, providing social } \\
\text { services }\end{array}$ \\
\hline LV3 & Founder & $\begin{array}{l}\text { SE project within } \\
\text { an LLC }\end{array}$ & $\begin{array}{l}\text { A social enterprise producing } \\
\text { tricycles and aid transport for } \\
\text { disabled people }\end{array}$ \\
\hline EST1 & Manager & NGO & $\begin{array}{l}\text { A rural village association } \\
\text { managing the village } \\
\text { community hall }\end{array}$ \\
\hline EST2 & Director & $\mathrm{NGO}$ & $\begin{array}{l}\text { An intermediary retail } \\
\text { enterprise sourcing and } \\
\text { delivering rural micro/SME } \\
\text { products }\end{array}$ \\
\hline EST3 & Board member & $\mathrm{NGO}$ & $\begin{array}{l}\text { A rural village association } \\
\text { delivering services for } \\
\text { children and young people } \\
\text { and managing the community } \\
\text { hall }\end{array}$ \\
\hline EST4 & Board member & Foundation & $\begin{array}{l}\text { A life-sharing community for } \\
\text { special needs adults }\end{array}$ \\
\hline
\end{tabular}

on the needs of their customers is one of the key reasons for their successful cooperation with the local government. In Lithuania, for example, the emphasis has been on inter-institutional trust in addressing customer needs; this is considered as a major factor enabling successful cooperation between social enterprises and local governments.

Social enterprises are usually specific in terms of services provided, and they cannot always encompass the entire scope of a tender when, for example, municipalities ask for large and diverse "packages" of services; 
in such cases, it often happens that individual social enterprises can offer only part of the required services. However, not all municipalities call for tenders for service delivery in one package. A positive point in this regard is the fact that the Public Procurement Law in Latvia provides for the principle of joint agreement, according to which all candidates meeting the criteria for public procurement have the right to enter the procurement contract, and the funding for specific services is later distributed separately. It means that funding received by each candidate in practice can differ, based on a price survey subsequently organised among all candidates for specific services. Significant changes also occurred in the field of public procurement following the transposition of the provisions of Directive 2014/24/EU of the European Parliament and of the Council of February 26, 2014, on public procurement into EU countries' national legal frameworks. One of the greatest achievements of the Directive is the transition from the application of the lowest-price criterion to a selection system of the best bid based on the price-to-quality ratio. The new Directive also introduces several important changes with regard to social entrepreneurs whose key goal is the social and professional integration of individuals from deprived and socially unprotected groups. Including the pursuit of a work-integration goal in the selection criteria can contribute to a choice that will be more sustainable and profitable in the long run, though bids including such goals might seem more expensive in a shortsighted perspective.

Cooperation with local governments is one of the best examples of long-term cooperation, as it requires a professional approach to accounting, reporting and needs assessment. Estonian social enterprises reported having quite a long history of cooperation with the municipality: EST4, for example, "has a long experience of cooperating with its municipality and has now entered a 20 -year contract with them to manage the village community hall, and they operate throughout the community, providing a range of social and care-based services".

\subsection{Challenges in Cooperation}

The three countries reported similar challenges for SE development and cooperation with different stakeholder groups.

One of the main challenges, more specifically linked to cooperation with the local government, is bureaucracy. This was clearly emphasised by reports from Latvia and Lithuania. For example, LV2 prepared a procurement delegation agreement and sent it to five municipalities, which each returned the agreement with amendments; these five agreements were then sent to the Ministry of Environmental Protection and Regional Development, which made further changes. As a result, LV2 received five quite different agreements; merging them into a single agreement required meetings with several ministries at different levels. 
These partnerships, though, get stronger through the definition of joint practices, and they enhance the competences of all the partners involved.

Trading with public authorities can be hindered by public-procurement requirements, which can lead public-sector actors to amalgamate their procurement contracts into large orders; this in turn restricts access to these procurement contracts for smaller social enterprises, which do not have the capacity to satisfy these. In rural areas, the requirement, for procurements below $€ 10,000$, to provide a price comparison between at least three suppliers can be difficult to meet when there are not three different companies in the local area capable of delivering the services requested; as a result, the procurement process may need to include a wider territory and take longer, or fail altogether.

The second challenge is linked to local governments' motivation and resources. Latvian and Lithuanian interviews revealed that the cooperation of social enterprises with the local government might be hindered in three ways: (1) the local government has neither the motivation nor the necessary resources to cooperate; (2) the local government is motivated but does not have sufficient resources to cooperate; and finally (3) the local government could find resources to cooperate with social enterprises but lacks the motivation to do so. Such a lack of motivation hinders the effective development of social enterprises.

Although social enterprises reported generally rather positive attitudes and good experiences in cooperating with local governments, "challenging cases" commonly occurred when the local government was motivated but had insufficient resources to cooperate. Indeed, local governments must have the necessary intellectual and human resources to establish and manage such partnerships. As reported by Latvian social enterprises, some local governments lack the human resources and institutional abilities to establish well-functioning partnerships between the public and private sectors. In such cases, social enterprises have to take the preparation of the entire "package of cooperation" into their own hands: preparing all the agreements and protocols, consulting experts on bureaucratic procedures, etc. It can be concluded that social enterprises often face quite stiff and formal bureaucratic attitudes, which may hinder their activities, as well as a lack of competence among municipality officials which slows down the pace of implementation of their activities.

Political and policy change at state and municipality level is the third factor hindering partnerships. Social enterprises can never be sure about the next procurement, not only because the local government could simply decide to withdraw its support but also because it might be forced to do so, due to budgetary constraints linked to external circumstances. Contract sustainability can also be problematic because local municipality politicians (and their direction and priorities) can change every few years. The demand for services can also grow to a point where it exceeds the delivery capacity of small social enterprises, which may then 
have to withdraw from providing these services or collaborate with other providers.

The fourth factor is the lack of business development and management skills among social entrepreneurs. Many leaders of community organisations do not have any particular training or knowledge in business management, project management, bookkeeping or tendering processes. Changes in legislation make the situation all the more complicated: SE leaders may feel that they do not know whether everything they are doing or want to do is legal.

As reported by Estonian social enterprises, making social enterprises sustainable would require good business models, and SE leaders have to understand that they have to choose services and/or products which they can sell. This understanding is sometimes hard to come by and since residents in their local communities often perceive that their problems are things that municipalities or governments should do something about and should also pay for, it can be a challenge to develop a viable business plan. There is a need to change these attitudes and to train people in how to develop and sell products and services.

The fifth hindering factor is the lack of knowledge and support for social enterprises among the lay public (rural residents), who may be insufficiently aware of social enterprise. Even though the situation has improved in recent years, many still do not understand the difference between a socially responsible enterprise, a social enterprise and a charity. Data are also lacking, in Latvia and Lithuania, on the social impact created by social enterprises.

The Estonian cases also highlighted a sixth hindering factor, namely a form of nepotism and/or the existence of bias in procurement processes. It appeared that where a key person in the municipality is closely connected with a social enterprise, there is a strong tendency for the service contract to be awarded to this particular enterprise, and other enterprises face huge challenges to be taken into consideration as potential providers. Tenders may also be framed to favour more established-rather than new—enterprises.

\subsection{Forms of Cooperation Implemented by the Stakeholders/ Clients}

Table 15.3 provides information about the stakeholder groups that play a key role in the development of social enterprises: governmental institutions and local governments, conventional enterprises, local communities, associations, SE networks, accelerators and business incubators and education institutions.

\section{Governmental Institutions and Municipalities}

In both Latvia and Estonia, social enterprises working in the field of social services often cooperate with municipalities through contracts to deliver 


\section{Evans, Raudsaar, Lìcite-Kurbe et al.}

Table 15.3 Main stakeholder groups of social enterprises in the Baltic states

\begin{tabular}{|c|c|c|c|}
\hline $\begin{array}{l}\text { Stakeholders/ } \\
\text { clients }\end{array}$ & $\begin{array}{l}\text { Forms of } \\
\text { cooperation } \\
\text { implemented by } \\
\text { the stakeholders/ } \\
\text { clients }\end{array}$ & $\begin{array}{l}\text { Factors fostering } \\
\text { cooperation }\end{array}$ & Challenges \\
\hline $\begin{array}{l}\text { Governmental } \\
\text { institutions/ } \\
\text { municipalities/ } \\
\text { local } \\
\text { governments }\end{array}$ & $\begin{array}{l}\text { - Buying social } \\
\text { and other } \\
\text { services } \\
\text { from social } \\
\text { enterprises } \\
\text { - Encouraging } \\
\text { SE activity } \\
\text { through public } \\
\text { tendering, } \\
\text { utilising } \\
\text { privileged } \\
\text { public- } \\
\text { procurement } \\
\text { procedures }\end{array}$ & $\begin{array}{l}\text { - Interest to } \\
\text { cooperate with } \\
\text { social enterprises } \\
\text { for the common } \\
\text { good } \\
\text { - New legislative } \\
\text { approaches at } \\
\text { EU level }\end{array}$ & $\begin{array}{l}\text { - Bureaucratic } \\
\text { attitude } \\
\text { - Strict } \\
\text { requirements of } \\
\text { public tenders } \\
\text { - Lack of } \\
\text { motivation to } \\
\text { cooperate with } \\
\text { social enterprises } \\
\text { - Demand for } \\
\text { services sometimes } \\
\text { exceeding the } \\
\text { capacity of social } \\
\text { enterprises } \\
\text { - Lack of } \\
\text { knowledge about } \\
\text { social enterprises }\end{array}$ \\
\hline $\begin{array}{c}\text { Conventional } \\
\text { enterprises }\end{array}$ & $\begin{array}{l}\text { - Buying } \\
\text { products/ } \\
\text { services } \\
\text { from social } \\
\text { enterprises } \\
\text { - Entering } \\
\text { into project } \\
\text { partnerships } \\
\text { with social } \\
\text { enterprises } \\
\text { - Becoming } \\
\text { social investors } \\
\text { in social } \\
\text { enterprises }\end{array}$ & $\begin{array}{l}\text { - Interest to } \\
\text { cooperate with } \\
\text { social enterprises } \\
\text { to improve their } \\
\text { image/reputation } \\
\text { (corporate social } \\
\text { responsibility) }\end{array}$ & $\begin{array}{l}\text { - Profit-oriented } \\
\text { enterprises, } \\
\text { with no special } \\
\text { interest in social } \\
\text { enterprises' social } \\
\text { mission }\end{array}$ \\
\hline Local community & $\begin{array}{l}\text { - Buying } \\
\text { products/ } \\
\text { services } \\
\text { from social } \\
\text { enterprises } \\
\text { - Disseminating } \\
\text { information } \\
\text { about social } \\
\text { enterprises }\end{array}$ & $\begin{array}{l}\text { - Generational } \\
\text { value change- } \\
\text { greater value } \\
\text { attributed to } \\
\text { work done by } \\
\text { hand, by socially } \\
\text { disadvantaged } \\
\text { groups of } \\
\text { people, etc. }\end{array}$ & $\begin{array}{l}\text { - Insufficient } \\
\text { information and } \\
\text { knowledge about } \\
\text { social enterprises } \\
\text { - Reluctance/ } \\
\text { incapacity to } \\
\text { pay the prices } \\
\text { charged by social } \\
\text { enterprises for } \\
\text { their products/ } \\
\text { services, which are } \\
\text { often higher than } \\
\text { those practiced } \\
\text { by conventional } \\
\text { enterprises }\end{array}$ \\
\hline
\end{tabular}




\begin{tabular}{|c|c|c|c|}
\hline $\begin{array}{l}\text { Stakeholders/ } \\
\text { clients }\end{array}$ & $\begin{array}{l}\text { Forms of } \\
\text { cooperation } \\
\text { implemented by } \\
\text { the stakeholders/ } \\
\text { clients }\end{array}$ & $\begin{array}{l}\text { Factors fostering } \\
\text { cooperation }\end{array}$ & Challenges \\
\hline $\begin{array}{l}\text { Other } \\
\text { stakeholders: } \\
\text { associations, } \\
\text { SE networks, } \\
\text { accelerators } \\
\text { and business } \\
\text { incubators } \\
\text { and education } \\
\text { institutions }\end{array}$ & $\begin{array}{l}\text { - Usually acting } \\
\text { as mentors, } \\
\text { advisors and } \\
\text { supporters }\end{array}$ & $\begin{array}{l}\text { - Creation of } \\
\text { new support } \\
\text { instruments/ } \\
\text { tools by different } \\
\text { stakeholders } \\
\text { (scholarships } \\
\text { and grants } \\
\text { for SE ideas' } \\
\text { implementation } \\
\text { set up by } \\
\text { associations and } \\
\text { SE networks) }\end{array}$ & $\begin{array}{l}\text { - Insufficient } \\
\text { information and } \\
\text { knowledge about } \\
\text { social enterprises }\end{array}$ \\
\hline
\end{tabular}

social services to various socially excluded groups. In Lithuania, local governments may also purchase goods or services from social enterprises.

Public-procurement contracts can be awarded to municipalities in two ways:

- The provision of services can be directly delegated to a social enterprise by the municipality through public procurement without a call for tenders being issued (there is thus no competition among service providers). The LV2 case has proved that such cooperation is possible; this social enterprise has at least 30 such agreements with local governments.

- The second form refers to a general public-procurement procedure, in which social enterprises compete through open tenders for localgovernment funding; social enterprises have proved to be competitive actors in such context. Since many social enterprises aim to improve the quality of life in the communities where they operate by performing functions traditionally or legally assigned to governmental institutions, they achieve such improvements through undertaking contracts for the provision of services outsourced by local governments.

However, very often, municipalities do not recognise social enterprises as social-service providers; this is especially true in Lithuania and Latvia. According to these two countries' laws regulating social enterprise (passed, respectively, in 2018, for Latvia, and in 2004, and amended in 2011, for Lithuania), an organisation cannot be recognised by municipalities as a social enterprise if it does not have the legal status of social enterprise. While there are considerable opportunities for growth, current 


\section{Evans, Raudsaar, Lìcìte-Kurbe et al.}

progress in this area is hindered by the lack of good practice that could inspire municipalities. There are a few salient examples, though, such as those offered by the municipality of Riga and the Latvian Ministry of Welfare, which bought catering services from a social enterprise for a specific event, but this is only a beginning, and cooperation between local authorities and social enterprises could be strengthened in the future. Indeed, whereas procurement practices for the provision of social services function well and have steadily developed over the last two decades, such practices remain poorly developed in the case of other services and products.

Social enterprises often cooperate with municipal institutions providing social services in rural areas in order to jointly design solutions to social problems; for example, municipalities' departments of social services acquire material aid in the form of clothing, footwear and/or food, which is then distributed among eligible individuals by social enterprises. A similar form of cooperation exists in the collection and distribution of food through food banks and sale of handicrafts made by the disabled. Collection and distribution of food and clothes are particularly important for ex-convicts as well as for persons in crisis centres. The social enterprise, by providing humanitarian aid through cooperation with a municipal partner, is able to achieve its social goals over a much wider area or to reach a larger target group-which incidentally contributes to its visibility and reputation (Kumaceva 2018).

Social enterprises may cooperate with state institutions not just as suppliers of goods and services but also as potential employers. For example, within the framework of cooperation with state employment agencies, social enterprises can employ job seekers under various programmes aimed at reducing unemployment among particular target groups (the disabled, the long-term or young unemployed, etc.).

Local and state government and their institutions (and in particular their departments in charge of social services and employment services) can act both as support partners for social enterprises and as buyers of their products/services.

\section{Conventional Enterprises}

Cooperation between conventional and social enterprises can take several forms and may involve the delegation of certain functions of the conventional enterprise to the social enterprise.

In one possible form of cooperation, the social enterprise operates as an autonomous and independent entity in organising and manufacturing its products, but these are all sold to a conventional enterprise, thus ensuring a guaranteed market and income. Social enterprises very often face challenges in selling their products, but in this cooperation model, 
the risk is reduced because the products are bought in advance by the conventional enterprise. Some conventional enterprises, for example, offer products produced by the disabled as their corporate gifts.

Some conventional enterprises have become social investors, and they may even collaborate in designing the operational strategy of the social enterprise.

Cooperation may also take the form of a project partnership. For example, LV2 successfully cooperates with conventional enterprises in that way. The food bank "For a Fed Latvia" (Paédušai Latvijai) has been running for ten years; since 2016, the private supermarket chain Rimi has become its partner and, as a result, the quantity of donated food has increased considerably.

\section{Local Community}

Social enterprises operate in various sectors, including inter alia social services, the production of goods, health services (including prevention), charity shops, environmental protection, cultural diversity and heritage, education, work integration, consulting, information and communication (Lis et al. 2017). Some social enterprises are well-known and recognised in society, while others are less familiar to the general public, because of their smaller scale, the limited geographic focus of their activity or their location in a rural or remote area. For this reason, clients of social enterprises operating in rural areas are primarily members of local communities.

Among members of the local community, knowledge and awareness of the nature of and social value created by social enterprises are lacking, and these enterprises tend to be confused with enterprises implementing corporate social responsibility (CSR) principles or with social work. A mistaken perception that social enterprises are primarily concerned with work integration also prevails. In a positive development, however, the ambassadors' network of the Social Entrepreneurship Association of Latvia organises events throughout the country, disseminating information about these events in social media and through websites; this results in successful information exchanges. During the events, social entrepreneurs often find new partners, which allows them to introduce new products or expand their businesses, and thus increases their competitiveness.

Despite the significant emigration mentioned earlier, positive trends in public thinking have also been observed across all Baltic states in recent years, largely due to the influence of generation Y (the demographic cohort born between 1980 and 1995), whose values tend to differ from those of previous generations. Millennials, as they are also called, are more concerned with the general public good, seek jobs that have meaning, think more about an efficient exploitation of limited resources, and 


\section{Evans, Raudsaar, Lìcite-Kurbe et al.}

are often ready to work towards social goals for little-or even noremuneration (Austruma 2012). This indicates a change in society's system of values and needs and is indicative of the fact that this generation seeks to achieve its ideals and is, therefore, likely to be interested in the establishment of social enterprises and willing to support their products.

\section{Other Stakeholders}

Business incubators are key early-stage support tools for social enterprises, particularly during the development stage; they provide premises and business-support services (legal advice, accountancy, expertise in business activities and marketing).

While universities are involved in training and research on social enterprises and are increasingly linking their theoretical knowledge with hands-on practice, social enterprises could provide an additional tool by becoming the first practical training or even the first job for students. Social enterprises can benefit in turn from the contribution of student trainees, who can undertake research on social enterprises, their social impacts and other business-development activities.

National associations/networks usually represent the interests of social enterprises at both national and local levels and cooperate with policyand decision-makers in establishing and developing well-functioning ecosystems for social enterprises.

\subsection{SE Typology in Rural Areas}

A synthetical and final way to characterise social enterprises in rural areas of the Baltic States might be to exploit the typology of SE models as elaborated by Defourny and Nyssens (2017) within the framework of the ICSEM Project. Table 15.4 summarises the key parameters of this analytical framework, highlighting the common trends that can be observed in the three Baltic countries as well as the SE models that prevail in each country.

\section{Principles of Interests}

In all three Baltic countries, rural social enterprises emerged primarily from the sector of NGOs providing public-benefit services. They try to satisfy general public needs, but their operations are mainly guided by the interests of the local community (with some exceptions, such as LV2, which covers all Latvian regions).

Most of the rural social enterprises in Lithuania are developed by active communities seeking to address social issues in the countryside through entrepreneurial initiatives that aim to improve the well-being of rural communities or a particular target group. Earned income is frequently 
Table 15.4 SE models in the Baltic States

\begin{tabular}{l|ll}
\hline \multicolumn{1}{|c|}{ Country } & Latvia & \multicolumn{1}{c}{ Lithuania } \\
\hline $\begin{array}{l}\text { Key parameters } \\
\text { interest }\end{array}$ & $\begin{array}{l}\text { Social enterprises provide goods/services meeting general } \\
\text { (mainly local community) interests and needs }\end{array}$ \\
\hline $\begin{array}{l}\text { Market reliance } \\
\text { and resource mix }\end{array}$ & Hybrid resources \\
\hline $\begin{array}{l}\text { Institutional } \\
\text { trajectories } \\
\text { generating SE } \\
\text { models }\end{array}$ & $\begin{array}{c}\text { Move towards more market-oriented activities in order } \\
\text { to complement existing resources }\end{array}$ \\
\hline $\begin{array}{l}\text { Prevailing SE } \\
\text { models }\end{array}$ & $\begin{array}{l}\text { Entrepreneurial non-profit } \\
\text { (ENP) model and social- }\end{array}$ & $\begin{array}{l}\text { Entrepreneurial non- } \\
\text { profit (ENP) model, } \\
\text { public-sector SE } \\
\text { model (PSE) and } \\
\text { business (SB) model }\end{array}$ \\
& & social-business (SB) \\
& & model \\
\hline
\end{tabular}

used to maintain a community home or support community activities (LT3). In many cases, Estonian NGOs were formed soon after the country regained its independence (EST4); the local municipality or a person closely connected to the municipality was often a founding member.

\section{Market Reliance and Resource Mix}

While social-service providers (e.g. LV2, EST1, EST4 and LT2) mainly rely on subsidies from municipalities, others rely to a larger extent on market income. In all Baltic countries, social enterprises combine a varied mix of resources including, to differing extents, income from market sales, public subsidies, grants and philanthropic (private grants) resources to balance their social mission and financial sustainability. They are continually looking for ways to diversify into new services/products to sell so as to generate market income (EST2 and EST3). Many rural social enterprises in Estonia are dependent on project grants, and they sometimes need help to identify other possible sources of income, while in Lithuania, they usually lack financially sustainable business models and are quite dependent on state support, funding from the European Social Fund, etc. (LT2 and LT3).

\section{Institutional Trajectories Generating SE Models}

In the three Baltic countries, rural social enterprises mainly use hybrid resources, address general (community) interests and move towards more market-oriented activities in order to complement their existing 
resources. In Estonia, social enterprises have close relationships with local municipalities and have been entrusted with the delivery of social services. In Lithuania, by contrast, social enterprises have rather weak partnerships with local public bodies; for example, the transfer of public and social service delivery to social enterprises has been slow, due to particular bureaucratic restrictions and a lack of trust between local public bodies and social entrepreneurs.

\section{Prevailing SE Models}

In Latvia, social enterprises largely develop from non-profit organisations and use "mission-driven-business" approaches. Many Latvian social enterprises thus belong to the entrepreneurial non-profit (ENP) model (some are de facto social enterprises; indeed, if they are not limited-liability companies, they are not legally recognised as social enterprises). Since 2018, as social enterprises have started to adopt a hybrid economic model, becoming more entrepreneurial, there has been a move towards the social-business (SB) model. This evolution is partly driven by the Social Enterprise Law, which requires that social enterprises operate under a commercial legal form.

The situation in Lithuania in terms of prevailing SE models presents similarities with that in Latvia as the ENP model is the most common form of social enterprise in Lithuanian remote rural areas. It has been greatly supported through EU funding aimed at creating opportunities and innovative ways to solve emerging social problems in these areas while strengthening the capacities of the non-governmental sector and rural communities. Also significant is the fact that social enterprises belonging to the SB model are gradually emerging in the country.

In Estonia, the main SE models are the public-sector SE (PSE) model and the social-business (SB) model. But in rural areas, the SB model is replaced by the ENP model, so the two prevailing models are the PSE model and the ENP model. PSEs are historically connected with local municipalities and serve the needs of municipalities; SBs are marketoriented, while ENPs are usually taking care of community's interests and use hybrid finance schemes.

\section{Conclusion}

The diversity of SE initiatives and the absence of a well-adapted and consensual conceptualisation result in a poor understanding of the concept in the three Baltic countries. While Estonia has no specific law or legal form for social enterprise, Lithuania has had a Social Enterprise Law since 2004, and Latvia since 2018. In Latvia, the definition of the SE concept is broad and includes a variety of activities, but the 
legal form is strictly defined (LLC). In Lithuania, by contrast, no specific legal form is required and social enterprises can take many forms, but the law narrowly defines the concept and, consequently, many socially oriented companies are not recognised as social enterprises. In Latvia and Lithuania, many social enterprises emerge from non-profit organisations applying "mission-driven-business" approaches. In these two countries, there are thus many ENPs, but the recent emergence of hybrid economic entrepreneurial models results in a move towards the SB model, while in Estonia, PSEs and SBs are the most common SE forms.

Beyond the blurry understanding of the concept, some similarities can be pointed out. In all three countries, many rural social enterprises emerge from the NGO/NPO sector. They provide public-benefit services, satisfy general public needs, and their operations cover local community interests. These social enterprises rely on a mix of various types of resources and use their market-oriented activities to complement their existing resources.

Finally, this chapter highlights the importance of collaboration with a variety of stakeholders as an essential driver for social enterprises and especially for rural social enterprises in order to succeed in their mission.

\section{References}

Annist, A. (2017) "Emigration and the changing meaning of estonian rural life", in Tammaru, T. (ed) Estonian Human Development Report 2016/2017 — Estonia at the Age of Migration, Foundation Estonian Cooperation Assembly. Available HTTP: https://saite.lv/Ct1Gl.

Atterton, J. (2007) “The 'strength of weak ties': Social networking by business owners in the highlands and Islands of Scotland", Sociologia Ruralis, Vol. 47, pp. $228-45$.

Austruma, S. (2012) The Values of the Youth in the Consumer Society of Latvia, Doctoral dissertation, Riga: Latvia University.

Borzaga, C. \& Depedri, S. (2015) "Multi-stakeholder governance in civil society organizations: Governance and democracy", in Laville, J.-L., Joung, D. \& Eynaud, P. (eds) Civil Society, the Third Sector and Social Enterprise: Governance and Democracy, London and New York: Routledge.

Butkute, J. (2014) "Kaimo gyvenviečių ir gyventojų skaičiaus, lytinès sudèties kaita 2001-2011 metais”, Geografija ir edukacija, Vol. 2, pp. 21-34.

Central Statistical Bureau of Latvia (2019a) Immigration, Emigration and Net Migration. Available HTTP: www.csb.gov.lv/en/statistics/statistics-bytheme/population/migration/key-indicator/immigration-emmigration-andnet-migration.

Central Statistical Bureau of Latvia (2019b) Migration in Latvia. Available HTTP: https://migracija.csb.gov.lv/?id=B1e0JusADQ. 


\section{Evans, Raudsaar, Lìcite-Kurbe et al.}

Central Statistical Bureau of Latvia (2020) Share of Persons Under Minimum Income Level by Statistical Regions of Latvia. Available HTTP: https://data1. csb.gov.lv/pxweb/en/sociala/sociala_nabadz_nevienl_min_ien/MIG020.px/.

Costa, E. \& Pesci, C. (2016) "Social impact measurement: Why do stakeholders matter?" Sustainability Accounting, Management and Policy Journal, Vol. 7, No. 1, pp. 99-124.

Courtney, R. (2013) Strategic Management in the Third Sector, New York: Palgrave Macmillan.

Dees, J. G. (2001) The Meaning of 'Social Entrepreneurship'. Available HTTP: https://entrepreneurship.duke.edu/news-item/the-meaning-of-social-entrepre neurship/ (accessed on March 6, 2020).

Defourny, J. \& Nyssens, M. (2017) “Fundamentals for an international typology of social enterprise models", Voluntas: International Journal of Voluntary and Nonprofit Organizations, Vol. 28, pp. 2469-97. Available HHTP: https://doi. org/10.1007/s11266-017-9884-7.

Di Domenico, M., Tracey, P. \& Haugh, H. (2009) “The dialectic of social exchange: Theorizing corporate-social enterprise collaboration", Organization Studies, Vol. 30, No. 8, pp. 887-907. Available HTTP: https:/doi. org/10.1177/0170840609334954.

Donaldson, T. \& Preston, L. E. (1995) "The stakeholder theory of the corporation: Concepts, evidence, and implications", Academy of Management Review, Vol. 20, No. 1, pp. 65-91. Available HTTP: http://dx.doi.org/10.2307/ 258887.

Erpf, P. (2017) "What is social entrepreneurship and how can it be differentiated from business entrepreneurship?" Swiss Journal of Business Research and Practice, Vol. 71, No. 2, pp. 197-208. Available HTTP: https://doi. org/10.5771/0042-059X-2017-2-197.

Erpf, P., Butkevičienè, E. \& Pučètaitè, R. (2020) "Between deJure and deFacto: Embedding Western concepts of social entrepreneurship in post-socialist reality", Journal of Social Entrepreneurship. Available HTTP: www.tandfonline. com/doi/full/10.1080/19420676.2020.1751245.

Eversole, R., Barraket, J. \& Luke, B. (2014) "Social enterprises in rural community development”, Community Development Journal, Vol. 49, No. 2, pp. 245-61. Available HTTP: https://doi.org/10.1093/cdj/bst030.

Freeman, R. E. (1994) “The politics of stakeholder theory: Some future directions”, Business Ethics Quarterly, Vol. 4, No. 4. pp. 409-21. Available HTTP: www.jstor.org/stable/3857340.

Galera, G. \& Borzaga, C. (2009) "Social enterprise: An international overview of its conceptual evolution and legal implementation", Social Enterprise Journal, Vol. 5, No. 3, pp. 210-28. Available HTTP: https://doi. org/10.1108/17508610911004313.

Hinrichs, L. (2015) "Social enterprises, hybridity, stakeholders, and social capital”, Otago Management Graduate Review, Vol. 21, pp. 21-31.

Jankauskaitè, J. (2019) Inequalities in Lithuania High Levels of Inequality in a Context of Rapid Economic Growth. Available HTTP: https://gcap.global/wpcontent/uploads/2019/06/9.3.a-report-LT.pdf.

Kumaceva, S. (2018) Biedrības “Tuvu” sociālās ietekmes novērtējums, Master thesis, Jelgava: Latvia University of Life Sciences and Technologies. 
Lis, A., Wallberg, N., Nordstrom, T., Šuvajevs, A. \& Ūlande, M. (2017) Social Enterprises and Municipalities: Cooperation, Partnerships and Synergies, Social Entrepreneurship Association of Latvia. Available HTTP: https://by.odb-office. eu/files/seandmunicipalities-en.pdf.

Munoz, S. A., Steiner, A. \& Farmer, J. (2015) "Processes of community-led social enterprise development: Learning from the rural context", Community Development Journal, Vol. 50, No. 3, pp. 478-93. Available HTTP: https://doi. org/10.1093/cdj/bsu055.

O’Shaughnessy, M., Casey, E. \& Enright, P. (2011) "Rural transport in peripheral rural areas: The role of social enterprises in meeting the needs of rural citizens”, Social Enterprise Journal, Vol. 7, No. 2, pp. 183-90. Available HTTP: https://doi.org/10.1108/17508611111156637.

Pārsla, E. (2011) "Padomju okupācijas demogrāfiskās, sociālās un morālās sekas Latvijā", Latvijas Zinātņu Akadēmijas Vēstis, Vol. 65, No. 3/4, pp. 86-106.

Perrini, F. \& Tencati, A. (2006) "Sustainability and stakeholder management: The need for new corporate performance evaluation and reporting systems", Business Strategy and the Environment, Vol. 15, No. 5, pp. 296-308. Available HTTP: https://doi.org/10.1002/bse.538.

Pless, N. M. (2012) "Social entrepreneurship in theory and practice-an introduction", Journal of Business Ethics, Vol. 111, pp. 317-20. Available HTTP: https://doi.org/10.1007/s10551-012-1533-x.

Raišienè, A. G. \& Urmanavičienè, A. (2017) "Mission drift in a hybrid organization: How can social business combine its dual goals?" Ekonomski Vjesnik/ Econviews, Vol. 30, No. 2, pp. 301-10.

Schöning, M. (2013) "Social entrepreneurs as main drivers of social innovation", in Osburg, T. \& Schmidpeter, R. (eds) Social Innovation, Berlin and Heidelberg: Springer Verlag, pp. 111-18. Available HTTP: https://doi. org/10.1007/978-3-642-36540-9_10.

Seney, B. \& Hess, D. B. (2018, August 8) "Population migration and Estonia: Adapting in an age of immigration", The Baltic Times. Available HTTP: https:// www.baltictimes.com/population_migration_and_estonia__adapting_in_ an_age_of_immigration/.

Simonaityte, V. (2019) “Žmogiškieji ištekliai”, in Kriščiukaitienè, I. \& Namiotko, V. (eds) Lietuvos žemés ir maisto ūkis 2018, Vilnius: Lithianian Institute of Agrarian Economics.

Smith, W. K., Gonin, M. \& Besharov, M. L. (2013) "Managing social-business tensions: A review and research agenda for social enterprise", Business Ethics Quarterly, Vol. 23, No. 3, pp. 407-42. Available HTTP: https://doi. org/10.5465/ambpp.2013.187.

Statistics Estonia (2018) Immigration Exceeded Emigration for the Third Year in a Row. Available HTTP: https://www.stat.ee/news-release-2018-050.

Statistics Lithuania (2019a) Population and International Migration. Available HTTP: https://osp.stat.gov.lt/lietuvos-gyventojai/lietuvos-gyventojai-2019/gyve ntoju-migracija1/tarptautine-migracija.

Statistics Lithuania (2019b) Population and Migration Inside of the State. Available HTTP: https://osp.stat.gov.lt/lietuvos-gyventojai/lietuvos-gyventojai-2019/ gyventoju-migracija1/vidaus-migracija_. 


\section{Evans, Raudsaar, Lìcite-Kurbe et al.}

Steiner, A. \& Teasdale, S. (2019) "Unlocking the potential of rural social enterprise”, Journal of Rural Studies, Vol. 70, pp. 144-54. Available HTTP: https:// doi.org/10.1016/j.jrurstud.2017.12.021.

Steinerowski, A. \& Steinerowska-Streb, I. (2012) "Can social enterprise contribute to creating sustainable rural communities? Using the lens of structuration theory to analyse the emergence of rural social enterprise", Local Economy, Vol. 27, pp. 167-82. Available HTTP: https://doi.org/10.1177/0269094211429650.

Thompson, J. L. \& Martin, F. (2010) Strategic Management: Awareness \& Change, Andover: South-Western Publishing Co. 